\title{
Does Business Income Tax Have an Effect on the Holding Behaviour of Institutional Investors? - Based on Experience Research of the Reform of Business Income Tax
}

\author{
Yanjun Xiang ${ }^{1}$, Yuan $\mathrm{Li}^{1,2}$ \\ ${ }^{1}$ School of Finance, Zhongnan University of Economics and Law, Wuhan, \\ 430073, China \\ ${ }^{2}$ Collaborative Innovation Center of Industrial Upgrading And Regional \\ Finance, Zhongnan University of Economics and Law, Wuhan, 430073, \\ China
}

\begin{abstract}
The impact of business income tax policy on the institutional investors in the capital market has not been paid extensive attention. This paper studies the problem under the situation of the implementation of new tax law in 2008. The analysis found that after the cancel of the deductible limit provisions of the equity investment, the institutional investor's holdings of stocks increased significantly. Moreover, different types of institutional investors will have different shareholding behaviors under the background of new tax law.
\end{abstract}

Keywords:business income tax, institutional investors, stock holding behaviors

\section{Introduction}

Before and after the implementation of the new tax law in 2008, there is a big difference in the two tax deductions of equity investment losses of Chinese enterprises. After the merger of the two taxes, the new enterprise income tax law and its supporting regulations, corporate investment for loss of tax deduction has no special provisions. At the same time, due to the state of the Securities Investment Fund temporarily exempt from enterprise income tax, the stock market funds institutional investors and other types of institutional investors. The 
effect of the implementation of the new tax law forms the conditions of a "natural experiment".

\section{Research design}

\subsection{Selection of indexes}

This paper mainly studies the influence of the new tax law on the institutional investors in 2008. In this paper, the proportion of institutional investors in the various quarters of the shareholding ratio as a reflection of changes in shareholding behavior indicators. When institutional investors in the previous quarter, when the overweight, the indicator is positive, when the reduction occurs, the index is negative. In the specific application, this paper carries on the logarithm processing after the addition of 1 , so that the estimation results of the double difference model can be directly interpreted as the percentage of the policy implementation to the shareholding changes.

\subsection{Source and processing of data}

The sample selected in this paper for the new tax law is from the first quarter of 2006 to the fourth quarter of 2007 for the event before the window period and the first quarter of 2008 to the fourth quarter of 2010 as the event window period. Institutional investors holding the data obtained from the Juling financial platform, Shanghai and Shenzhen 300 index data obtained from CSMAR database of Guotai Junan.

\section{Empirical results and analysis}

\subsection{Analysis of overall influence}

Table 1 shows the regression results of the annual population samples obtained by using the double difference model. From the double difference statistics can be seen in the control of the other factors of institutional investors and behavior after the implementation of the new tax law to other types of institutional investors holding funds other than the behavior change. In the overall sample, under the condition of two types of holdings, the double difference statistics are significant. 
Table 1 Testing results of double difference of an overall annual sample

\begin{tabular}{|c|c|c|c|}
\hline \multirow[b]{2}{*}{ Variable's name } & \multicolumn{2}{|c|}{ Random effect } & \multirow{2}{*}{$\begin{array}{l}\text { Stable effect } \\
\text { Decreased } \\
\text { sample }\end{array}$} \\
\hline & Full sample & $\begin{array}{l}\text { Increased } \\
\text { sample }\end{array}$ & \\
\hline \multirow{2}{*}{ Time dummy variable } & -0.011 & 0.005 & 0.001 \\
\hline & $(1.58)$ & $(0.57)$ & $(0.98)$ \\
\hline \multirow{3}{*}{ Group dummy variable } & -0.040 & -0.047 & \\
\hline & $(4.70)^{* * *}$ & $(3.98)^{* * *}$ & \\
\hline & 0.047 & 0.057 & 0.001 \\
\hline Double difference statistics & $(6.06)^{* * *}$ & $(5.47)^{* * *}$ & $(1.45)$ \\
\hline \multirow{2}{*}{$\begin{array}{c}\text { Number of present stock } \\
\text { holding }\end{array}$} & 0.033 & 0.042 & 0.001 \\
\hline & $(6.70)^{* * *}$ & $(5.86)^{* * *}$ & $(4.17)^{* * *}$ \\
\hline $\begin{array}{l}\text { Number of stock holding in } \\
\text { the previous period }\end{array}$ & $\begin{array}{c}-0.032 \\
(6.24)^{* * *}\end{array}$ & $\begin{array}{c}-0.047 \\
(6.54)^{* * *}\end{array}$ & $\begin{array}{c}-0.001 \\
(3.14)^{* * *}\end{array}$ \\
\hline $\begin{array}{l}\text { Market value of present } \\
\text { stock holding }\end{array}$ & $\begin{array}{c}0.008 \\
(1.70)^{*}\end{array}$ & $\begin{array}{c}0.021 \\
(3.02)^{* * *}\end{array}$ & $\begin{array}{l}0.000 \\
(0.12)\end{array}$ \\
\hline \multirow{2}{*}{$\begin{array}{l}\text { Market value of stock } \\
\text { holding in the previous } \\
\text { period }\end{array}$} & -0.011 & -0.016 & 0.001 \\
\hline & $(2.17)^{* *}$ & $(2.26)^{* *}$ & $(1.24)$ \\
\hline \multirow{2}{*}{ CSI 300} & 0.000 & 0.000 & -0.000 \\
\hline & $(1.34)$ & $(0.73)$ & $(0.37)$ \\
\hline \multirow{2}{*}{ Return rate of CSI 300} & -0.004 & -0.005 & 0.000 \\
\hline & $(0.83)$ & $(0.80)$ & $(0.79)$ \\
\hline \multirow{2}{*}{ Constant } & 0.018 & -0.064 & -0.010 \\
\hline & $(0.93)$ & $(2.21)^{* *}$ & $(5.30)^{* * *}$ \\
\hline Fit goodness & & & 0.26 \\
\hline Number of observations & 2,848 & 2,004 & 736 \\
\hline \multicolumn{4}{|c|}{$\begin{array}{l}\text { Notes: The data in the brackets are the } \mathrm{T} \text { statistics of every coefficient. }{ }^{*}, * * \text { and } \\
* * * \text { respectively represent the significance under } 10 \%, 5 \% \text { and } 1 \% \text { confident } \\
\text { level. }\end{array}$} \\
\hline \multicolumn{4}{|c|}{$\begin{array}{l}\text { Table } 2 \text { shows the regression results obtained by using the double difference } \\
\text { model. It can be observed that different environmental samples in all four quarter, } \\
\text { double difference statistics showed a greater difference, with quarterly changes, } \\
\text { there are significant differences between symbol directions dual difference } \\
\text { statistics, the implementation of the new income tax law that rules, brings } \\
\text { institutional investors holding behavior point selection. }\end{array}$} \\
\hline
\end{tabular}


differences in the direction and degree of change. In addition to the financial institutions and financial products, other institutional investors have appeared to increase the ratio of stock movements and the reduction of the ratio of stock movements decreased.

Table 3 Testing results of double difference of different types of institutional investors of an annual sample

\begin{tabular}{|c|c|c|c|c|}
\hline $\begin{array}{l}\text { Institution } \\
\text { type }\end{array}$ & Variable's name & Full sample & $\begin{array}{l}\text { Increased } \\
\text { sample }\end{array}$ & $\begin{array}{c}\text { Decreased } \\
\text { sample }\end{array}$ \\
\hline \multirow{5}{*}{ Broker } & Time dummy & -0.015 & -0.008 & 0.003 \\
\hline & variable & $(4.09) * * *$ & $(1.82)^{*}$ & $(0.51)$ \\
\hline & Double difference & 0.021 & 0.017 & 0.001 \\
\hline & statistics & $(3.13)^{* * *}$ & $(2.39)^{* *}$ & $(0.16)$ \\
\hline & Fit goodness & 0.48 & 0.54 & 0.34 \\
\hline \multirow{7}{*}{ Insurance } & Time dummy & -0.020 & -0.010 & -0.035 \\
\hline & variable & $(3.93) * * *$ & $(1.67)^{*}$ & $(1.54)$ \\
\hline & Group dummy & & & -0.070 \\
\hline & variable & & & $(3.43)^{* * *}$ \\
\hline & Double difference & 0.116 & 0.115 & 0.087 \\
\hline & statistics & $(9.49)^{* * *}$ & $(9.12)^{* * *}$ & $(3.65)^{* * *}$ \\
\hline & Fit goodness & 0.47 & 0.56 & \\
\hline \multirow{5}{*}{$\begin{array}{l}\text { Ordinary } \\
\text { companies }\end{array}$} & Time dummy & -0.003 & 0.006 & 0.011 \\
\hline & variable & $(0.41)$ & $(0.72)$ & $(0.37)$ \\
\hline & Double difference & 0.062 & 0.061 & 0.064 \\
\hline & statistics & $(6.27)^{* * *}$ & $(5.53)^{* * *}$ & $(1.98)^{* *}$ \\
\hline & Fit goodness & 0.20 & 0.21 & 0.14 \\
\hline \multirow{6}{*}{ Trust } & Time dummy & -0.018 & -0.005 & -0.011 \\
\hline & variable & $(4.48)^{* * *}$ & $(1.11)$ & $(0.90)$ \\
\hline & Group dummy & -0.096 & -0.102 & -0.059 \\
\hline & variable & $(7.90)^{* * *}$ & $(8.52)^{* * *}$ & $(3.60)^{* * *}$ \\
\hline & Double difference & 0.094 & 0.107 & 0.052 \\
\hline & $\begin{array}{c}\text { statistics } \\
\text { Fit goodness }\end{array}$ & $(7.14)^{* * *}$ & $(8.34)^{* * *}$ & $(3.30)^{* * *}$ \\
\hline \multirow{7}{*}{$\begin{array}{c}\text { Finance } \\
\text { companies }\end{array}$} & Time dummy & -0.015 & -0.001 & -0.019 \\
\hline & variable & $(3.49) * * *$ & $(0.27)$ & $(1.16)$ \\
\hline & Group dummy & & & 0.068 \\
\hline & variable & & & $(2.57)^{* *}$ \\
\hline & Double difference & -0.027 & -0.018 & -0.084 \\
\hline & statistics & $(1.33)$ & $(0.89)$ & $(2.98) * * *$ \\
\hline & Fit goodness & 0.50 & 0.61 & \\
\hline \multirow{7}{*}{$\begin{array}{c}\text { Wealth } \\
\text { management } \\
\text { companies }\end{array}$} & Time dummy & -0.015 & -0.003 & -0.001 \\
\hline & variable & $(4.06)^{* * *}$ & $(0.70)$ & $(1.16)$ \\
\hline & Group dummy & & & 0.001 \\
\hline & variable & & & $(1.62)$ \\
\hline & Double difference & -0.001 & -0.022 & 0.002 \\
\hline & statistics & $(0.07)$ & $(2.56)^{* *}$ & $(2.05)^{* *}$ \\
\hline & Fit goodness & 0.51 & 0.61 & \\
\hline
\end{tabular}


Notes: The data in the brackets are the T statistics of every coefficient. *,** and $* * *$ respectively represent the significance under $10 \%, 5 \%$ and $1 \%$ confident level.

\section{Conclusion}

Based on the double difference model, this paper studies the effect of the new tax law on the trading behaviour of institutional investors in China in 2008, which mainly includes the following three points.

(1) On the whole, the new tax law has a significant impact on the institutional investors' shareholding behaviour, which makes institutional investors tend to hold more stocks. They may increase or decrease the holdings of stocks.

(2) The new tax law on the whole promotes the increasing holdings behaviour of institutional investors and supresses the decreasing holdings behaviour of institutional investors. They would like to increaseholdings in the second quarter and the fourth quarter. The decreasing holdings behaviours may occurin the first quarter, second quarter and the fourth quarter. The impact of the new tax law of the holding behaviours in the third quarter is not significant.

(3) The new tax law has different effects on different types of institutional investors. Except the financial institutions and the wealth management companies, the impact of the majority of institutional investors of the new tax law is consistent with the overall impact. There are similar situations in the periods.

The empirical evidence of this paper shows that the government can change the institutional investors' ownership and transaction behaviour through the adjustment of corporate tax policy, but the response of different types of institutional investors should be fully considered.

\section{References}

[1] Chyz, J.A., Li, O.Z., Do tax sensitive investors liquidate appreciated shares after a capital gains tax rate reduction? , National Tax Journal 65(3), pp. 595-628, 2012.

[2] Dyl, E., Capital gains taxation and year-end stock market behavior, Journal of Finance 32, pp. 165-175, 1977.

[3] Gibson, S., Safieddine, A., Titman, S., Tax-motivated trading and price pressure: an analysis of mutual fund holdings, Journal of Financial and Quantitative Analysis 35(3), pp. 369-386, 2000.

[4] Jin, L., Capital gains tax overhang and price pressure, Journal of Finance 61(3), pp. 1399-1430, 2006.

[5] Sialm, C., Starks, L., Mutual fund tax clienteles, Journal of Finance 67(4), pp. 1397-1422, 2012. 